\title{
An investigation into Communicative English Language Needs and Perceptions of English for Specific Purposes Course: The Case of Holy Trinity Theological College
}

\author{
Amare Tesfie Birhan \\ Bahir Dar Institute of Technology, Bahir Dar University, Ethiopia \\ amaretesfie@gmail.com
}

First draft received: 29 May 2019 Date Accepted: 9 Jul 2019 Final proof received: 27 Aug 2019

\begin{abstract}
This research aimed to investigate the communicative English language needs of Holy Trinity Theological College students. To this end, mixed methods approach was undertaken using questionnaires, interviews and course book (module) analysis. The participants of the study were students, employees, English course instructors, content area instructors. The samples were chosen through availability and purposive sampling. Descriptive statistics and thematic analysis were employed to analyse the data. The findings indicate that students used English language to read and understand professional courses, to communicate freely with English speakers, to prepare religious journals, to present papers in seminaries, to translate books, and to preach the Bible abroad. The respondents preferred courses that contain both professional and academic linguistic items and discourses to use the language in their professional and academic contexts. Furthermore, the text evaluation indicated that the materials were designed without considering theology students' professional language needs and expectations. Finally, it is recommended that syllabus designers and material writers should consider the communicative English language needs of theology students identified in the study.

Keywords: English for specific purposes; Holy Trinity Theology College; need analysis; perception

To cite this paper (in APA style):

Birhan, A. T. (2019). An investigation into communicative English language needs and perceptions of English for specific purposes course: The case of Holy Trinity Theological College. International Journal of Education, 12(1),26-33. doi: 10.17509/ije.v12i1.17509
\end{abstract}

\section{INTRODUCTION}

English is a widely spoken language in the world, and it is the only lingua franca language (Jha, 2013; Zikmundova, 2016) which is spoken by millions of people as first, second, and foreign language levels. As a result of greater needs of the language use in different contexts, English for specific purposes came into existence in the 1960s (Paltridge \& Starfield, 2013; Richards, 2001). Since then, the application and usage of English for specific purposes has been the focus of various researchers (Hutchinson \& Waters, 1987). This increasing focus is mainly due to the growing needs to use the language internationally in commerce, engineering, medicine, law, culture, tourism and religious activities, fields or situations, (Crystal, 2003; Richards, 2008). Besides, learners are also seeking language skill or competency in the target language in specific domains to use it for communication. As Paltridge and Starfield (2013) mentioned, learners need to develop specific English language skills to use it in a particular domain.

Hence, English for specific purposes (ESP) focuses on developing the communication skill of learners in specific disciplines. The courses are designed with learner-centred approaches in order to achieve the designed objectives. Therefore, to determine the communicative language needs of various disciplines, language experts and researchers applied needs analysis as a tool. According to DudleyEvans and St. John (1998), needs analysis is the backbone of ESP; it asks questions about students' needs, wants, expectations and features of the actual teaching which they use in their profession.

In this regard, Brown (1995) defines needs analysis as "

the collection and analysis of all subjective and objective information necessary to define and validate defensible curriculum purposes that satisfy the language learning 
requirements of students within the context of particular institutions that influence the learning and teaching situations. (p. 36)

Designing a course that meets the specific needs of learners helps to enhance learners' conceptions, motivation, and engagement to learn a language, and will later help learners to function effectively and efficiently in their professional life.

To design English for specific purposes courses, various procedures should be considered. The first procedure is needs analysis; it is an umbrella concept which encompasses subjective, objective, target and present situation analysis. The objective needs analysis includes analysing learners' level of language proficiency, their perceived language difficulties and their demand of language in the real communicative context (Nunan, 1988; Brindley, 1989). Whereas, the subjective needs analysis includes the affective needs, expectations, preferred learning styles, previous learning experiences, self-esteem and reasons for attending the course (Nunan, 1988; Mehrdad, 2011; Brindley, 1989).

Similarly, it is also important to consider the target situation and the present situation needs of the learners. The present situation analysis refers to analysing learners' current language skills and language use; this should be done at the beginning of the course. This analysis helps to understand what learners already know and to suggest what they should learn. Likewise, the target situation needs analysis refers to getting information about the reason why students need to learn the language (Robinson, 1991; Nunan, 1988; Dudley Evans \& St. John, 1998). Therefore, it is important to include all these four issues while analysing the language needs of the learners.

Furthermore, the material that is designed to be implemented in ESP courses should be assessed based on whether or not it addresses the communicative needs of the learners. If the material does not address the communicative needs of the learners, linguistic items, skills or any other missed issues can be incorporated, and these could be achieved with clear and objective assessment criteria.

In Ethiopia, teaching English has a long history, and it has become an instructional language in primary to higher education. Moreover, it is used by media, entertainment, and governmental and nongovernmental agencies as a second official language. Consequently, the ministry of education directs all students who enrol in college and university to take courses such as communicative English, basic writing skills, technical report writing skills, and English for lawyers (only by law students) for the purpose of improving learners' communicative skills in using the language in their profession.

Holy Trinity Theological College is one of the university colleges in the Ethiopia Orthodox Church which accepts students and teaches religious and secular courses, and students who enrol in the college take mainly college English I and II and sophomore
English with the purposes of using English for communication purposes. However, these courses do not include many linguistic items, expressions and genres which appear in students' profession. It was assumed that learning those courses was not enough to understand and practice the many literary terms and expressions that appear in students' profession and academic context in particular and in the church services in general.

Early studies on ESP such as those by Abraham (1993), Mekasha (1994), Habtamu (2008), and Tufaro (2009), in Ethiopia as well as by international researchers (Chovancova, 2014; Moslehifar \& Ibrahim, 2012; Nakamura, 2014; Zafarghandi, Sabet, \& Delijani, 2017) explored the necessities of teaching English for specific purposes courses to satisfy the communicative needs of the learners. However, to the researcher's best knowledge there has been no research specifically addressing the communicative English language needs of Holy Trinity theology college occupational and professional English language communicative needs.

Therefore, this research was conducted in the light of research works which focused on communicative English language needs of those college students. This research hypothesised that Holy Trinity Theology students learn English language by taking courses which do not satisfy their occupational communicative language needs, and various authentic and specialized linguistic items do not appear in the courses which they take. Hence, the general objective of this research was to explore the communicative English language needs of Holy Trinity Theology University College students and their preference language courses. It also endeavoured to explore learners', instructors', and employees' perceptions towards ESP courses. Based on the above general objectives, the following research questions were formulated.

1. What are the communicative language needs of the students in a theological college in Ethiopia?

2. How do students and instructors in the theological college perceive English for professional purposes?

3. To what extent do the courses being offered address theology students' communicative language needs?

\section{METHOD \\ Research Design}

The researcher gathered the qualitative and quantitative data simultaneously or sequentially in order to answer the proposed research questions. Hence, the research was designed through an embedded mixed methods design. Particularly, the qualitative data were gathered by interview and course book (module) analysis and the quantitative data were gathered through questionnaire. 


\section{Participants and Sampling Procedures}

The research aimed to explore communicative English language needs of students and their perceptions for specific purposes course. Hence, the research was conducted at Holy Trinity University College of the Ethiopian Orthodox church in Addis Ababa, Ethiopia. In accordance of the nature of the research, students, employees, English courses instructors, and content area (theology) courses instructors who were teaching courses through English language participated in the study. Moreover, three teaching materials were also analysed. To choose the sample, purposive and availability sampling procedures were used. Specifically, two English language instructors and two content area instructors were selected through purposive sampling technique, and 10 employees and 80 students were selected through availability sampling procedures.

Out of the 70 theology students who filled in and returned the questionnaire, 48 of them were between 20 and 30 years old. 17 students were between 31 and 40 years old, 3 respondents were between 41 and 50 years old, and the other 2 respondents were over 51 years old. They also had different educational levels. $48.6 \%$ of the respondents finished grade 10 , $25.7 \%$ of respondents completed grade $12,20 \%$ of respondents graduated with a diploma and the other $5.7 \%$ of respondents had a degree. In addition, 10 employees and 2 content area instructors participated in the study.

\section{Procedures and Instruments}

To gather the data, the researcher followed two procedures: determining the samples and gathering data. Though, it was difficult to get actual number of students who enrolled in the college in different programs, the researcher decided to take 80 students through availability sampling. In the study, first year students were excluded because they took only one course while the data were gathered. It may be difficult for them to give comments on the courses they did not take. Accordingly, after the samples were selected, training was given to the students who participated in data gathering. Then, the questionnaire items were translated into the official language of Ethiopia, Amharic, and administered to the samples. $98 \%$ of the respondents properly filled in and returned the questionnaire. In addition, semi- structured interview was conducted with the instructors parallel with the questionnaire data.

To ensure its validity, the researchers adopted questionnaire items from previous researchers (Abraham, 1993; Hailemariam, 1993; Abebe, 1997;
Habtamu, 2008; Aman, 2011; Hutchinson \& Waters, 1987). Secondly, the items were commented and revised by students who pursue a PhD program in English language and literature.

Questionnaires, as the main instrument prepared for both students and employees, were designed using Likert scales of 5-1(5, always 4, usually, 3, sometimes, 2 rarely and 1, never) and 1-3 most preferred, second preferred, and least preferred, respectively. The major themes of the questionnaires were when they use English language in their occupation, how much it satisfies their communication needs, how frequent they use English for professional communication, and what kind of courses they prefer.

The other instrument was a semi-structured interview. This was used in order to assess the general attitudes and practices of the instructors on students' language ability and English courses. Semistructured interview items were prepared for both English instructors and theology or content area instructors with the aim of supplementary data asked in student and employee questionnaires. It covered students' need, expected objectives of learning the language, and an evaluation of whether or not the courses were related to students professional study. The items were adapted from Hutchinson and Waters (1987).

Lastly, the researcher conducted a textual analysis. This tool was used to triangulate the data which were gathered through questionnaires and interviews. The analysis was administered to check whether or not the course being offered to theology students would satisfy the academic and professional communicative language needs of theology students. The researcher evaluated college English I and II, and sophomore English course books. The researcher prepared checklists adapted from Hutchison and Waters, (1987), Cunningsworth (1984). Among the items in the checklist, some of them are: whether or not the material carefully considers the learners' needs, meets the objectives, is appropriate to the learners' needs, includes specialist linguistics items that are related to the subject area; and whether or not the learners are equipped with skills and strategies that will allow them to operate effectively in English in professional situation, there is a balance between subject specific language items and operational skills and strategies in language use, and the extent to which the learning activities mirror real life situations.

Finally, the collected data were tallied and analysed quantitatively and qualitatively. The quantitative data were computed using SPSS to obtain the mean, frequency, and percentage of each item. 
These quantitative data were put in tables and descriptive analysis. On the other hand, the qualitative data from students' questionnaire, the instructors' interview, and text book analysis were analysed qualitatively.

\section{RESULTS AND DISCUSSION}

To compute learners' and employees' communicative language needs and the extent of their language use in their occupation, descriptive statistics was run. Accordingly, both employees' and students' responses are summarized in Table 1 . Both employees and students were asked to rate the extent to which they used English for communicative purpose in their profession.

Table 1 Students communicative needs in their profession $\begin{array}{llllll}\text { Situations } & \text { Always Usually Sometimes Rarely Never }\end{array}$

\begin{tabular}{|c|c|c|c|c|c|c|c|c|c|c|c|}
\hline & & $\mathbf{F}$ & $\mathbf{P}$ & $\mathbf{F}$ & $\mathbf{p}$ & $\mathbf{F}$ & $\mathbf{p}$ & $\mathbf{F}$ & $\mathbf{p}$ & $\mathbf{F}$ & $\mathbf{p}$ \\
\hline \multirow[t]{2}{*}{ In preaching } & EM & - & - & - & - & - & - & 1 & 10 & 9 & 90 \\
\hline & ST & - & - & - & - & 1 & 1.4 & 7 & 10 & 62 & 88.6 \\
\hline \multirow[t]{2}{*}{ In Counselling } & EM & - & - & - & - & 4 & 40 & 4 & 40 & 2 & 20 \\
\hline & ST & 1 & 1.4 & 3 & 4.3 & 3 & 4.3 & 5 & 7.1 & 58 & 82.9 \\
\hline \multirow[t]{2}{*}{ In reading religious books } & EM & 4 & 40 & 4 & 40 & 1 & 10 & 1 & 10 & - & - \\
\hline & ST & 18 & 25.7 & 37 & 52.9 & 9 & 12.9 & 3 & 4.3 & 3 & 4.3 \\
\hline \multirow[t]{2}{*}{ In Mass } & EM & - & - & - & - & - & - & - & - & 10 & 100 \\
\hline & ST & 2 & 2.9 & 4 & 5.9 & - & - & - & - & 64 & 91.4 \\
\hline \multirow[t]{2}{*}{ In presenting papers and work shop } & EM & 6 & 60 & 2 & 20 & 1 & 10 & - & - & 1 & 10 \\
\hline & ST & 8 & 11.4 & 29 & 41.4 & 21 & 30 & 2 & 2.9 & 10 & 14.3 \\
\hline $\begin{array}{l}f=\text { frequency } \\
P=\text { percent }\end{array}$ & & 列 & $\begin{array}{l}\text { ts } \\
\text { yee }\end{array}$ & & & & & & & & \\
\hline
\end{tabular}

As indicated in the Table 1, 90\% and $88.6 \%$ of employees and students, respectively, reported that they did not use English language for preaching purposes. Similarly, $40 \%$ of employees and $58 \%$ of students stated that the English courses that they took never prepared them for counselling purposes. In Ethiopian Orthodox Church, priests and preachers have great responsibility to give moral, religious and psychological counselling services. However, the courses they took pose a challenge to give international counselling service. In order to read international and national religious books, both Students (52.9\% usually, 25\% always) and employees (40\% always, $40 \%$ usually) stated that they frequently used the language. Likewise, $60 \%$ of employees and $41.4 \%$ of students stated that they used the language to give presentation in the workshop. On the contrary, $100 \%$ and $91.4 \%$ of employees and students, respectively, stated that the courses they took did not equip them to use the language to give mass service. Hence, they perceived it difficult to use the language during church mass.

In addition to the above data, both content area and English language instructors stated that English language is very important for theologians though tasks, activities and exercises, were different from theological or professional languages. They mentioned all languages skills are very important for theology students. Specifically, students used speaking, writing and reading skills in regular frequency. The instructors agreed the skills are very important to preach, read and understand the Bible and ministry, and to give religious presentations. Moreover, they stated that professional language was very essential to understand different academic and for theological materials, to prepare for a theological conference, theological literature, to write a lot of religious argumentative text, preach the Bible abroad and to listen and understand international religious ceremonies.

\section{Employees and Students' Perceptions towards ESP course}

Students were also asked to indicate preferences for topic areas of English for which their studies should be focused. As shown in Table 2, a majority (80\%) of students indicated that their first preference was a balance between topics from general and professional English. They perceived a balance between general and professional English very important for them in order to use in their academic and occupational situations. They also ranked professional English second and general English third as preferred topics of interest. 
Table 2 Students' perceptions of ESP course

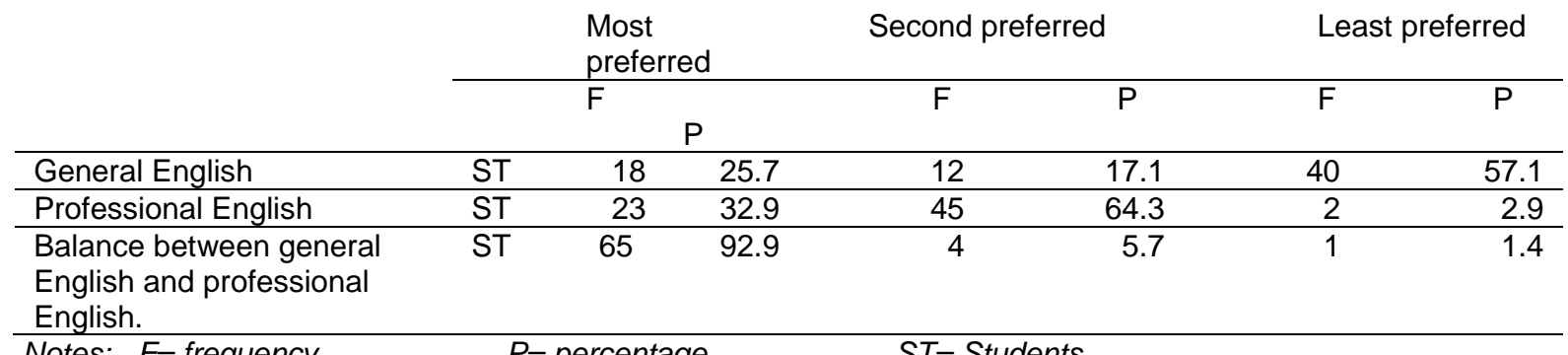

Notes: $F=$ frequency $\quad P=$ percentage

The above data indicated both students' and instructors' language needs were to have English language competency that enabled them to be competent language users in their professional and academic communicative situations. During the interview, content area and English language instructors recommended that the contents of the English courses should be related to theology courses; they added that the courses must include some theological terms and expressions to fit with major courses. They perceived that all language skills should be emphasized to fit with theological terms and expressions and enable them to use in their occupation; the students would write professional journals, theological books, prepare for theological conferences and preach the Bible abroad. Therefore, they stated that the courses must be designed to enhance students' language problems and enable them use the language skills for different professional activities.

\section{Learners Communicative Needs vs the Module}

In the college, the students took College English I and II and sophomore English courses. Thus, an attempt was made to examine those course books. The course books were evaluated by using the checklists which were developed by Cunningsworth (1984) and Hutchinson and Waters (1987). These checklists were employed to examine whether or not the materials adequately satisfy the English language needs of theology students.

The first item was whether or not the courses carefully analysed students' needs. The course helps students improve writing paragraphs, letters, essays, CVs and reading skills which they used in their academic contexts. Moreover, the contents of the courses included both receptive and productive skills in addition to grammar and vocabulary. In each language skill, different items were explained. Likewise, the contents of sophomore English were good for students' academic communicative language need. They slightly help what students want to work with writing. However, the researcher found that both college English and sophomore English contents did not include theological terms and expressions, and there were no core specialist genres related to theology. The courses were designed without analysing theology students professional communicative language needs.

The other item assessed was the teaching material objectives and distribution of language skills. Both college English course books have seven different units and each unit has its own objectives. The course books include listening, speaking, writing, reading, grammar and vocabulary. Those language skills are important in students' academic studies, and they were designed to help students explore many concepts independently, to think, explore and share their views freely and manage academic demands effectively. On the other hand, sophomore English was designed to enable them to compose comprehensive sentences and paragraph, and to edit written texts. But the mentioned objectives were general objectives. Those objectives did not include all objectives that theology students wanted to achieve at the end of the English courses in their profession.

Furthermore, the flexibility of the material was assessed, and it was found that the courses were not fully and sufficiently flexible. Some units were difficult if students missed the class. For example, sophomore English module was organized as word, phrase, sentences, paragraph, and essay. If students did not understand the first section of the course, they would not understand the other section. In relation to allowing modular structure, there are two approaches. Some units of the courses allow modular structure, and other units do not. In addition, students who did not learn section one of the units could not easily learn and understand the other sections and units of the courses. Generally, the materials were designed through a mix of sequential and non-sequential ways.

In addition, the material did not have clear and essential explanations, examples, tasks, pictures and other illustrations which are appropriate for individual study. As a result, it seemed difficult for individual independent learning; they require teachers' follow-up, explanations and guidance.

The last point was the learning activities had outcomes or products that would help learners to evaluate their performance. The researcher found that in the beginning of the units the general objectives of the materials were specified. In addition, within each unit there were various tasks and exercise which could be used as self-assessment mechanism. Those tasks and exercises helped them to evaluate their performances. Accordingly, the textbooks do not seem 
to respond to the professional communicative needs of theology students, and they did not employ languages and expressions linked a particular profession or discipline. Though researchers such as Richards (2001) argue that students are studying English in order to carry out a particular role in their occupation, the material does not sufficient to satisfy their communicative needs.

The courses were designed to promote students' language knowledge in various aspects. These may help students in some aspects, but they did not satisfy many of the elements an ESP material should treat. Furthermore, those courses could not prepare them for their occupation and make them familiar with professional linguistic expressions, lexes and genres. The ESP materials help to use language effectively for their purpose, and the courses must base their considerations on what students want to learn (Cunningsworth, 1984). This argument is resonated in the Bible, such as in Psalm 150, that says:

Praise God in his sanctuary

Praise him with the sound of trumpet

Praise him with psaltery

Praise him with tumbrel with stringed

instrument and organs

Praise him upon the loud cymbals

Praise him up on the high sounding cymbal

The instructors also recommended courses which were given to them were not enough to use the language in different church activities except the students had other experiences and words and expressions specifically which appear in mass and preaching are not familiar words, and it is not easy to use those words and expressions in English. They added that if the courses were revised and included theological linguistic items and expressions, students would become more interested than at the present time.

Generally, the courses were not deemed to appropriately prepare students to participate in different occupational situations. Thus, the material must be revised and related to theology students' needs. Vocabulary, reading, writing and grammatical contents of the modules (course books) must fit with theological language, and the reading texts should be taken from religious texts, and every other aspect of the language must fit theology.

\section{Discussion}

Having good communication skills is one of the fundamental aspects in language learning (Moslehifar \& Ibrahim, 2012; Chatsungnoen, 2015). Thus, to achieve good communication with the target language, students need to learn courses which satisfy their needs and communication gaps. Accordingly, this research has great implication for learners, instructors, curriculum designers and language policy makers.

The research indicated theology students preferred to learn courses which they need to use in both general and specific purposes. The students need to use the language for their professions. These findings were in correspondence with those of Chovancova (2014), Moslehifar and Ibrahim (2012), Nakamura (2014), and Zafarghandi, Sabet and Delijani (2017). who mentioned that learners need to learn English language contents and skills that can satisfy their communicative needs.

The present research also revealed that students' communicative needs and courses were unrelated. Students rarely used the language for their occupation purposes because of inadequacy of the teaching material to corpuses which can be utilized in their communication. This finding entails that instructors who teach at Holy Trinity University College need to consider the communicative needs of their students, and they may have to incorporate authentic linguistics items and corpuses while they teach the courses. They may also have to identify the students' communication gaps and diagnose students' language competency. Chovancova (2014) recommended:

The aim of ESP course is to provide targeted language instruction that addresses the students' real communicative needs in students' professional situations. The teachers have responsibilities to support students to become functional members of their professional communities by achieving their linguistics needs. (p. 56)

Moreover, the research implies that syllabus designers may have to design courses which are appropriate to theology students' language needs.

It was also found that most students came from the Ethiopian Orthodox church school/abenet temhertbet, and they did not use the English language. Only $10 \%$ of students could have conversation at academic level with the instructors and $20 \%$ of students were unable to answer basic conversation questions, understand easy texts, and write correct sentences. The students who do not have good language competency may not be interested to engage in language classes and activities. Besides, the learners varied in their educational level and age, and these differences may affect their communicative language needs. Students' second language acquisition and proficiency are intervened by age, aptitude, intelligence, attitude and motivation (de Bot, Lowie \& Verspoor, 2005). As a result, offering the same course for these various groups of students will seem difficult, and the varying communicative needs of the students will not be met. Some students may need a course for basic communication purposes, while the others need a course to help them use English for a variety of professional situations.

\section{CONCLUSIONS}

This study was conducted to explore the communicative needs of English language at Holy Trinity theological college. It was found that though students needed to learn courses related to their profession, the course materials which were used in the college did not have professional and academic genres (professional language and expressions) to 
help them use the language in different professional settings or situations. As a result, a majority of students faced difficulty to learn English.

Understanding the role and practice of English language in the workplace is one of the concerns of ESP (Marra, 2013). Hence, the teacher should analyse the needs of the learners and design a course or courses that can help prepare them for their future career. It has to be understood that the learners need good communicative competency to perform professional tasks. Likewise, the material should include rhetorical genres, linguistic items, expressions, collocations that are related and commonly used in theology. Basturkmen (2010) stated that the ESP course design includes specific language skills that the students will need. Therefore, it is important to consider the communicative English language needs of the learners. In addition, the instructors should always assess the difficulties of their students and provide assistance and work on students' weakness. In order to minimize students' language competency difference, additional and varying activity seems important. Thus, the college has to design additional courses which help to enhance students' communicative skills.

In this study, certain limitations were observed. The study involved only one college, and it did not seek to determine the effect of the courses on learners' communicative skills. Hence, it would be interesting and useful if future research includes other theology colleges. Future research may also use experimental design to examine the effects of ESP courses on learners' communicative skills.

\section{REFERENCES}

Abebe, M. (1997). Developing criteria for designing an appropriate English course for technical students. (Unpublished MA thesis), Addis Ababa University, Ethiopia.

Abraham, M. (1993). Developing criteria for a course in English for air craft technicians of the Ethiopian aircraft. (Unpublished MA thesis). Addis Ababa University, Ethiopia.

Aman, T. (2011). An investigation in to the English language needs of hotel and tourism management students: Hawassa University in Focus (Unpublished MA thesis). Addis Ababa University, Ethiopia.

Basturkmen, H. (2010). Developing courses in English for Specific Purposes. London: Palgrave MacMillan.

Brindley, G. (1989). The role of needs analysis in adult ESL programme design. In R. K. Johnson (ed.), The second language curriculum (63-78). Cambridge: Cambridge University Press.

Brown, J. (1995). The elements of language curriculum: A systematic approach to program development. Boston: Heinle and Heninle Publishers.

Chatsungnoen, P. (2015). Needs analysis for an English for specific purposes (ESP) course for
Thai undergraduates in a food science and technology programme (Unpublished PhD Thesis). Massey University, Palmerston North.

Chovancova', B. (2014). Needs analysis and ESP course design: Self-perception of language needs among pre-service students. Studies in Logic, Grammar and Rhetoric, 38(51), 43-57.

Crystal, D. (2003). English as a global language. Cambridge: Cambridge University Press.

Cunningsworth, A. (1984). Evaluating and selecting EFL teaching materials. London: Heinemann Education.

de Bot, K., Lowie, W., \& Verspoor, M. (2005). Second language acquisition: An advanced resource book. New York: Routledge.

Dudley-Evans, T., \& St. John, J. (1998). Development in English for Specific Purpose. A multidisciplinary approach. Cambridge: Cambridge University Press.

Jha, S. K. (2013). English in Eastern Ethiopia is learnt: Not Mastered. English Language Teaching, 6(4), 42-55.

Habtamu, D. (2008). English language needs analysis of fine arts students at Mekele College of Teacher Education (Unpublished MA thesis). Addis Ababa University, Ethiopia.

Hailemariam, K. (1993). Establishing criteria for designing an appropriate English Course for the Yared Music School, (Unpublished MA thesis), Addis Ababa University, Ethiopia.

Hutchinson, T. \& Waters, A. (1987). English for Specific Purpose: A learner-centred approach. Cambridge: Cambridge University Press.

Marra, M. (2013). English in the work place. In B. Paltridge and S. Starfield (ed.), The handbook of English for specific purposes (pp. 175-192). New Jersey: John Wiley \& Sons, Inc.

Mehrdad, A. G. (2012). A subjective needs assessment of EGP students. Procedia-Social and Behavioral Science, 31, 546-554

Mekasha, T.(1994). A study of the syllabus of unity private language schools in relation to the needs of the learners. (Unpublished MA thesis), Addis Ababa University, Ethiopia.

Moslehifar, M. A., \& Ibrahim, N. A. (2012). English language oral communication needs at the workplace: Feedback from human resource development (HRD) trainees. Procedia-Social and Behavioural Sciences, 66, , 529-536.

Nakamura, J. (2014). Work place English language needs of Japanese Business undergraduates. OnCUE Journal, 7(3), 151-167.

Nunan, D. (1988). The learner-centred curriculum. Cambridge: Cambridge University Press.

Paltridge, B., \& Starfield, S. (2013). The handbook of English for Specific Purposes. New Jersey: John Wiley \& Sons, Inc.

Richards, J. (2001). Curriculum development in language teaching. Cambridge: Cambridge University Press.

Richards, J. (2008). Teaching speaking and listening: 
From theory to practice. Cambridge. Cambridge University Press.

Robinson, P (1991). ESP Today: A Practitioner's Guide. New York: Prentice Hall International UK. Ltd.

Tufaro, B. (2009). English language needs assessment of Shashamanne Health Science College students: $10+3$ in Focus. (Unpublished MA thesis). Addis Ababa University, Ethiopia.

Zafarghandi, A. M., Sabet, M.K., \& Delijani, Y. K. (2017). An investigation into the effectiveness of an ESP course: A case study of graduate students of psychology. Journal of Applied Linguistics and Language Research, 4(2), 57-80.

Zikmundova E. (2016). English as Lingua franca: Theory and practical implications. (Unpublished Thesis). University of West Bohemia is a university in Pilsen, Czech Republic. 